\title{
DE ACCOUNTANT BIJ FAILLISSEMENT EN BIJ SURSEANCE VAN BETALING
}

\author{
door H.J. Reyn
}

Inleiding.

Het is bevreemdend, dat in het veelgebruikte boek ..Inleiding tot de leer van de accountantscontrole" van de heren J. E. Spinosa Catella en L. G. van der Hoek in het kader van hun behandeling van onderzoekingen met een bijzonder doel geen hoofdstuk is gewijd aan de functie van de accountant bij faillissement. In het aan het boek toegevoegde zakenregister komt het woord "faillissement" zelfs niet voor. Wel wordt in hoofdstuk XXI beperkt aandacht besteed aan de surseance van betaling. Hoewel de auteurs in hun Voorwoord bij de tweede druk zeggen ",niet naar volledigheid te hebben gestreefd", meen ik dat deze omissie betreurenswaardig is. Immers, juist bij faillissement kan de accountant een maatschappelijk zeer belangrijke functie vervullen. Het doel van dit artikel is een formulering van de inhoud van deze functie te geven. Het is ingedeeld in:

A. De functie van de accountant bij faillissement en

B. De functie van de accountant bij surseance van betaling.

\section{A. De functie van de accountant bij faillissement \\ Jutidische kenschetsing}

Het juridisch karakter van het faillissement is: beslag op het gehele vermogen van de schuldenaar, omdat deze ,in de toestand verkeert, dat hij heeft opgehouden te betalen" (art. 1 F.W.) Dit beslag bedoelt de uitwinning van de boedel, dus het te gelde maken van alle vermogensrechten van de schuldenaar om met de verkregen middelen de schuldeisers - voorzover mogelijk - te voldoen. Deze uitwinning wordt in art. $68 \mathrm{~F}$.W. opgedragen aan de curator. Hij beheert en vereffent. $Z_{i j n}$ beheer en vereffening staan onder toezicht van de rechter-commissaris. (art. 64 F.W.) Beide functionarissen worden aangesteld door de bevoegde rechtbank.

\section{Controle door rechter-commissaris}

De taak van de curator is derhalve vermogensbeheer, beheer van aan derden toebehorend vermogen. Hij is dus rekenplichtig. Terecht stelt de wet hierop een controle in, in de figuur van de rechter-commissaris. Echter, is deze controle voldoende? Is de rechter-commissaris voor deze controle de juiste persoon? Beschikt hij als regel over de controletechnische deskundigheid om zijn controle doelmatig te doen zijn? Dit is niet het geval! De rechter-commissaris is een jurist, lid van de in het faillissement bevoegde rechtbank. Hij behoort niet tot de groep van deskundigen op het gebied van de controle op gegeven verslagen omtrent gevoerd beheer. Voorts is een aantal handelingen onttrokken aan de bevoegdheid van de curator en kunnen deze beheersdaden alleen door of met medewerking van de rechtercommissaris worden verricht. De wet vermengt derhalve beheer en controle. Uiteraard speelt bij de beoordeling van deze door de wet geschapen constructie de - buiten twijfel staande - integriteit van de rechter-commissaris geen rol.

\section{Discussies van 1937}

Reeds in 1937 is het functioneel onjuiste van de door de wet ingestelde 
controle in juristenkringen aan de orde gesteld, met name door Mr. Dirkzwager. Men verwees naar de in een aantal gevallen geconstateerde tekorten en weet deze met name aan het geen gebruik maken van de wettelijk geschapen waarborgen als het storten der boedelgelden bij de ontvanger voor de gerechtelijke consignatiën (art. $92 \mathrm{~F}$.W.) en aan het niet-naleven van de voorschriften van art. $102 \mathrm{~F}$.W. Omdat men de oorzaken der tekorten zag in onjuist beheer der gelden, is het begrijpelijk dat men de oplossing zag in de benoeming van een geldbewaarder qua professie: de bank, tot medecurator. Over dit voorstel volgde een felle discussie, waaraan vrijwel uitsluitend juristen deelnamen, doch welke niet tot positieve conclusies voerde. Begrijpelijk. In de eerste plaats omdat het toezicht in de beschouwingen werd geconcretiseerd als: toezicht op de bewaring der gelden. Een onaanvaardbare beperking, gebaseerd op een onjuist bedrijfseconomisch inzicht. Behartigenswaardig is in dit verband, hetgeen de heer Keuzenkamp in 1938 schreef: „De voornaamste reden waarom bij rekenplichtigen tekorten ontstaan, moet niet worden gezocht in de vermenging van kassen, doch in het gemis van een of meer van de karaktereigenschappen, die nodig zijn voor de vervulling der functie van rekenplichtige." In de tweede plaats kon de discussie van 1937 niet tot een doelmatige conclusie voeren, omdat men - op een enkele uitzondering na - de aanwezigheid verwaarloosde van een groep, uitgerust met specialistische kennis op het gebied van de controle: de accountants. Slechts schuchter drong Prof. Mr Cleveringa - één der weinigen die het probleem scherp zag - er op aan, zich in daartoe geëigende gevallen te bedienen van een accountant. Hiermee formuleerde hij de

\section{Eerste functie van de accountant}

namelijk die van controleur van de verslaglegging omtrent het gevoerde beheer door de curator. De wet laat de benoeming van de accountant in zodanige functie nadrukkelijk toe, met name in art. $66 \mathrm{~F}$.W., dat de rechtercommissaris de benoeming van een deskundige toestaat .,ter opheldering van alle omstandigheden het faillissement betreffende."

\section{Tweede functie van de accountant}

Heeft de eerste functie van de accountant tot inhoud de controle op de curator, een tweede functie, welke de accountant als deskundige bij een faillissement van een onderneming kan vervullen, is die van hulpverlening aan de curator. Op welke wijze kan dit geschieden? Uiteraard alleen voor werkzaamheden welke de accountant uit hoofde van zijn deskundiaheid beter kan verrichten dan de curator, welke jurist is. Als zodanig zijn te noemen:

1e. de vaststelling van de vermogenstoestand van de schuldenaar per de datum van faillietverklarina. De wet schriift in art. 194 voor. dat de curator .zo snoediq mocelijk overaat tot het opmaken van eene beschrijvina des faillieten boedels" en art. 96 verplicht hem ,dadelijk na de beschrijving van de hoedel over te gaan tot het onmaken van een staat, waaruit de aard en het bedrag van de baten en schulden des boedels blijken." Wij bevinden ons hier wel ten volle op het terrein van de accountant.

$2 e$. het verlenen van assistentie bij de verificatie der vorderingen, zoals de wet deze in de artikelen 108-137 aan de curator opdraaat.

$3 e$. het onderzook naar de oorzaken van de situatie en het geven van een oordeel omtrent eventuele toekomstmogelijkheden. Vooral in het kader van art. 98 F.W. dat de curator de hevoegdheid geeft het bedrijf van de 
gefailleerde voort te zetten, is een zodanig onderzoek van groot belang.

4 . het onderzoek naar het plegen van actio pauliana, handelingen, door de gefailleerde vóór de faillietverklaring onverplicht verricht waardoor de schuldeisers benadeeld zijn, terwijl ,,bij het verrichten der handeling zowel de schuldenaars als degene met wien of te wiens behoeve hij handelde de wetenschap bezat, dat daarvan benadeling der schuldeisers het gevolg zoude zijn" (art. 42 F.W.) Deze handelingen kunnen tegenover de boedel als nietig worden beschouwd.

Deze onvolledige opsomming toont reeds hoezeer de accountant de curator van dienst kan zijn bij de uitvoering van diens door de wet aangegeven taak. Uiteraard mag de inschakeling van een accountant nimmer tot gevolg hebben, dat de curator zijn beherende functie ten dele overdraagt aan de accountant. Het "beheer en de vereffening" zijn bij uitsluiting van ieder ander de taak van de curator, doch hieraan doet de inschakeling van des kundigen niet tekort.

Tot de adviserende functie van de accountant behoren ook de werk zaamheden welke de accountant kan verrichten terzake van een accoord. De wet laat partijen (schuldenaar en schuldeisers) vrij een regeling te treffen, een accoord. De curator dient over dit accoord advies te geven (art. 140 F.W.) aan de rechtbank, welke de regeling — ingevolge artikel 153 F.W. - moet homologeren. De accountant is m.i. de aangewezene om de curator ten deze van advies te dienen.

\section{De kosten}

Uiteraard brengt de inschakeling van een accountant voor de boedel kosten met zich. Wie dient deze kosten te betalen? Het komt ons juist voor, deze ten laste van de boedel te brengen als preferente schuld. Een doelmatige controle immers is een direct belang voor de boedelcrediteuren. Zulks temeer waar - ik citeer de heer Keuzenkamp - ,de met een deskundig boekenonderzoek aanvangende opmaking van de staat van baten en schulden menigmaal transacties uit voorafgaande perioden en het bestaan van activa aan het licht zal brengen, waarvan de wetenschap voor de boedel van belang is."

Een probleem ontstaat bij de kleinere faillissementen. De baten zullen hier vaak gering of nihil zijn, zodat er geen mogelijkheid bestaat tot betaling van een accountantshonorarium. Destijds is voorgesteld een omslagkas in te stellen, waarin een percentage uit alle faillissementsbaten zou worden gestort en waaruit de accountantshonoraria zouden kunnen worden betaald. De heer James Polak achtte het aanvaardbaar iedere accountant te verplichten bij toerbeurt een faillissementscontrole ,pro deo" te verrichten. In hoeverre deze methoden succes zouden hebben, onttrekt zich aan onze beoordeling. Vast staat echter, dat „wij het maatschappelijk verkeer een dienst bewijzen, indien wij de benoeming van een accountant als controleur in een faillissement daarop niet laten stuiten." ( J. Kraayenhof)

\section{Accountant en curator}

In hoeverre bestaan bezwaren tegen de benoeming van een accountant tot curator? Deze vraag is uitvoerig besproken op de op 4 October 1941 gehouden ledenvergadering van het Nederlands Instituut van Accountants, met name door de heren J. Kraayenhof en J. P. de Haan. De eerstgenoemde achtte de benoeming van een accountant tot curator niet gewenst, omdat de accountant hiermee een beheersfunctie anvaardt en de mogelijkheid bestaat, dat hij zich daarmede komt te bewegen als beheerder op een gebied, 
waarop ook van zijn controle-cliënten werkzaam zijn. De heer De Haan meende, dat ,waar het uitoefenen der functie van curator niet geschiedt in de uitoefening van een beroep, doch zuiver beschouwd moet worden als het uitvoeren van op zichzelf staande werkzaamheden", het ongewenst was de accountant als zodanig uit te schakelen.

In dit verband zij gewezen op een artikel van de heer Keuzenkamp in het $M A B$ van Juni 1938. Genoemde zag als oplossing voor het ontbreken van een doelmatige beheerscontrole de benoeming van een accountant tot mede-curator met beperkte bevoegdheid. Het onjuiste element in deze gedachte is dat de accountant als zodanig een beheersfunctie aanvaardt. Weliswaar wil de heer Keuzenkamp de curatorsarbeid van de accountant beperken tot bepaalde - binnen zijn deskundigheid gelegen - werkzaamheden, doch zal het maatschappelijk verkeer zulks aanvaarden, verstaan? M.i. zal het de accountant zonder meer als "compleet curator" zien.

Op identieke gronden komt mij de gedachte van de heer De Haan onjuist voor. Het maatschappelijk verkeer zal de accountant, optredend als curator, van zijn accountantsfunctie niet los kunnen denken. Het zal verwachten, dat de accountant de curatorswerkzaamheden wèl verricht ,in de uitoefening van een beroep", n.l. het accountantsberoep.

De accountant dient zich dan ook, zoals de heer Kraayenhof reeds in 1941 stelde, te onthouden van een optreden als curator. Op een zodanig voorstel dient hij positief „neen" te zeggen. Even positief als hij een opdracht tot controle van de boedel moet aanvaarden, ook als de vergoeding daarvoor lager dan gebruikelijk zou zijn.

\section{$B$. De functie van de accountant bij surseance van betaling}

\section{Juridische kenschetsing}

Surseance van betaling verschilt principieel van het faillissement. Ontneemt faillissement de gefailleerde zijn vermogen, bij surseance behoudt de schuldenaar het recht tot handelen, doch moet rekening houden met een door de rechtbank aangewezen mede-beheerder, de bewindvoerder. Direct na het aanvragen van surseance door de schuldenaar wordt deze voorlopig verleend en kan een deskundige aangewezen worden, welke een onderzoek in moet stellen naar de staat van boedel (art. 226 F.W.) Dit onderzoek moet voeren tot een oordeel omtrent de betrouwbaarheid van de door de schuldenaar overgelegde staat van baten en schulden van de boedel en omtrent de vooruitzichten ten aanzien van de vraag of de schuldenaar na verloop van tijd zijn schuldeisers zal kunnen bevredigen; het verslag omtrent het onderzoek moet zo mogelijk de maatregelen aangeven. welke tot die bevrediging kunnen leiden.

Wordt de gevraagde surseance verleend, dan heeft dit - zoals gezegd tot gevolg, dat de schuldenaar slechts daden van beheer betreffende de boedel verrichten kan met .,medewerking, machtiging of bijstand" van de bewindvoerder. Iedere drie maanden moet deze een verslag uitbrengen over de toestand van de boedel en ter griffie neerleggen, ter kosteloze inzage van een ieder (art. 227 F.W.)

\section{Functies van de accountant}

Welke functies kan de accountant bij de surseance vervullen?

In de eerste plaats die van deskundige in de zin van art. 226 F.W., welke dus is belast met het onderzoek naar de staat van de boedel en met het geven van een oordeel omtrent de mogelijkheid de schuldeisers na

m a b blz. 86 
verloop van tijd te voldoen. Enerzijds dus een zelfstandig balansonderzoek, anderzijds een investigation met een prospectief karakter. Dus een controlerende en een adviserende functie.

Een tweede aspect van de adviserende functie van de accountant is aanwezig, indien de schuldenaar aan schuldeisers een accoord aanbiedt, n.l. het uitbrengen van een verslag omtrent de aanvaardbaarheid van het aangeboden accoord.

Bestaat er voor de accountant bij surseance van betaling ook een controlefunctie, identiek aan die waartoe voor het geval van faillissement werd geconstateerd? M.i. is dit inderdaad het geval. Enerzijds omdat de bewindvoerder, hoewel in eerste instantie een toezichthoudende taak hebbende, mede-beheert. Anderzijds omdat hij door zijn controle de bewindvoerder van grote steun kan zijn. met name als het een onderneming van ingewikkelde structuur of grote omvang betreft.

Accountant en bewindvoerder.

$\mathrm{Na}$ hetgeen hierboven is gesteld omtrent de benoeming van een accountant tot curator, behoeft het geen nadere toelichting, dat ook de benoeming van een accountant tot bewindvoerder onwenselijk is.

\section{Slotopmerking}

De benoeming van een accountant tot controleur van een failliete boedel of ingeval van surseance van betaling is niet verplicht. Ik acht dit een maatschappelijk onaanvaardbare situatie. .Ieder" - aldus de heer Keuzen kamp - ,die in het bedrijfsleven met rekenplichtigen in aanraking komt, acht controle op de door hen overgelegde verantwoording de meest natuurlijke zaak. Er is geen enkele reden, waarom afgestudeerden in de rechten, wanneer $z \mathrm{ij}$ in dat bedrijfsleven een rekenplichtige functie te vervullen krijgen, zich zouden mogen onttrekken aan de controle, die het bedrijfsleven nodig acht." Moge dit artikel er toe bijdragen, de aandacht opnieuw met nadruk op deze aangelegenheid te richten. Ook hier geldt zeker „,frappez, frappez toujours"! 